\title{
PRESENT APPROACHES TO EVALUATION OF ANTHROPOGENOUS CHANGES IN LANDSCAPE AS A FACTOR OF FLOOD RISK
}

J. Langhammer, V. Vilímek: Present approaches to evaluation of anthropogenous changes in landscape as a factor of flood risk. - Geografie-Sborník ČGS, 111,3 , pp. 233-246 (2006). - Flood risks can be evaluated from two points of view, the economic and the process one. The economic approach parts from consequences of the causal event when the risk is defined as the function of probability of occurrence of a certain phenomenon and of potential damage. The process approach evaluates the risk via main processes and factors involved in the risk development. The risk is then defined on the basis of three factors - hazard, exposure, vulnerability (Barredo et al. 2005, Crichton 1999, Kron 2003). Anthropogenous changes in the landscape represent, according to the process approach to risks, one of the vulnerability factors. Vulnerability of environment in relation to values exposed to the hazard represents their susceptibility to damage occurrence and is decisive for the extent of damage. Large changes in intensity, character and structure of land-use occurring in the cultural landscape during these last centuries, affect changes in outflow conditions of the catchment and can thus influence the course of floods. Vulnerability is a risk element which can be, differently from the other risk components, at least partly influenced and controlled. While natural processes representing a source of hazard cannot be influenced and accumulation of property in flood areas can be only hardly reduced, it is possible to purposefully reduce vulnerability both of natural environment and of social links in a way to minimize consequences of natural elements activities, to increase the efficiency of flood control measures and to limit damages to a strict minimum corresponding to the extremity of the phenomenon.

KEY WORDS: natural hazards - floods - risk - land-use - anthropogenic changes.

The presented research was funded by the Research Plan MSM 0021620831 "Geographical Systems and Risk Processes in Context of Global Changes and European Integration" of the Czech Ministry of Education and Research Project VaV-SM/2/57/05 "Long-term changes of river ecosystems in floodplains affected by extreme floods" of the Ministry of Environment of the Czech Republic which is fully appreciated by the authors.

\section{Introduction}

An increased settlement density and growing financial and technical requirements of buildings make it necessary for the society to ensure the most effective protection possible against both direct and indirect consequences of natural disasters. At the same time however, people influence natural environment to such a degree that they largely contribute to deterioration of the given situation. However, also quite natural changes occur simultaneously in the physical-geographical sphere (as for instance valley and erosional network development) which have nothing in common with 
human impact as they manifested already in the palaeogeographical history of the Earth and they will occur also in future. Some of these processes go on very slowly and in long perspective, others, on the contrary, in a catastrophic way. Exactly differentiation of intensity of the impact of human society on the course of natural processes may help to ensure protection against natural disasters.

Floods as one of many types of natural hazards have their causes and consequences and they are also bound to some other types of natural disasters. They belong to the category of hydrometeorological events, but they are bound to other types of natural hazards as well (e.g. Kukal 1982, Vilímek 2003). This subject matter is also dealt with in general publications on natural hazards (e.g. Bolt et al. 1975, Alexander 1993).

With regard to requirements of management of risks, we are in a situation, when governmental bodies ask scientific workplaces not only to identify the hazards but also to quantify the risks. It is crucial for a successful quantification to determine the degree of risk (of the process intensity), the probability of occurrence in the given locality (region) and the most precise time possible when risk processes set in. Different kinds of natural hazards offer different possibilities how to solve these tasks in dependence on our more or less detailed knowledge of respective components of physicalgeographical sphere. For instance earthquakes occur often without previous symptoms, volcanic activities are mostly intensifying gradually as well as flood risk, on the other side flash floods manifest a much quicker development of critical state.

Because of the complexity of physical-geographical sphere, the degree of interconnection between individual components and a still limited degree of knowledge of some natural processes, it is sometimes very difficult and even impossible to quantify the natural hazard with the necessary precision. And consequently it is difficult for governmental bodies to determine adequate preventive measures (including the decision to evacuate population). In case of a too late reaction or an insufficient degree of prevention, there are human and material losses and when, on the contrary, the risk is overestimated, future mistrust of population is probable and financial costs are qualified as superfluous. And floods are not an exception.

\section{Risks and approaches to their assessment}

Mutual relationship of natural hazards and risks was summarily dealt with for instance in the paper by Vilímek (2003), and that mainly in respect of floods and other kinds of natural hazards. Flood hazard is defined for instance by Alexander (1993) as "threat to life or property posed by rising or spilling water". The term risk is often used in different connections and contexts. It is used not only with regard to natural processes, but also in social, economic, security or environmental spheres and its understanding, delimitation and usage are generally different in each of these spheres. But as it is necessary to have a clear definition for analysing, assessing and controlling risks, several methodological approaches have progressively developed to enable to define, assess and consequently also to control the risks.

Main current approaches to risk understanding are represented by two views - an economic and a process one. The economic approach evaluates the 
risks from the perspective of consequences of the causal event when the risk is defined as function of probability of occurrence of a certain phenomenon and of a possible damage. The process approach assesses the risk through the main processes and factors involved in the risk emergence. The process approach is a significant contribution to assessment and modelling of the risk and a basis of many evaluation approaches used in natural sciences as well as in practical applications. The risk is defined by three factors - hazard, exposure, vulnerability (Barredo et al. 2005, Crichton 1999, Kron 2003):

$$
R=O \times E \times Z
$$

where $R$ is risk, $O$ - hazard, $E$ - exposure and $Z$ - vulnerability. These three components act in synergy and interaction, but they differ by their origin, character and manifestations.

The component of hazard in the process conception is represented by the proper stochastic natural process causing threats to natural or social system. In the case of flood risk there are causal processes causing the flood itself atmospheric precipitations, snow melting, or processes causing dam ruptures.

The component of exposure represents potential for damage emergence, as it includes property in the areas exposed to natural process threat. In case of floods there are for instance residential and commercial structures, industrial areas, movable property, communications, agricultural facilities, etc., which are endangered.

Vulnerability can be defined as predisposition to damage occurrence (HZS 2006). In the system of natural risks it represents a binding element determining the course of a natural hazard, the character of its consequences and the resulting extent of damage. It can be evaluated in relation to the both remaining factors of the risk - exposure and hazard. These two vulnerability aspects being different - the first one represents vulnerability of socioeconomic structures and links, the second one vulnerability of the natural environment.

Mutual relationship of the given three risk components can be expressed by a triangle, where individual components are represented by its sides and the resulting degree of risk by the area of the triangle (Fig. 1). The risk emerges only when all its components are greater than zero. If we eliminate any of the risk components, the risk disappears.

The process concept of risk understanding is an important contribution to management of and protection against the risk of natural disasters. It enables to better understand and assess the significance of individual factors for the intensity of the risk that differ for individual situations, geographical areas and time periods and, according to the character of the risk, to choose corresponding methods for its mitigation or elimination.

\section{Anthropogenous changes in landscape as a factor of vulnerability}

Anthropogenous changes in landscape are, according to the process approach to risks, one of the factors of vulnerability. The scheme in Figure 2 shows the position of floods in context of relationship cause-consequence, and that both natural and anthropogenous. The principle of development of systems with non-linear dynamism, in literature as a rule called "chaos theory", "complexity theory" or "self-organized criticality" (Viles 2005), must 


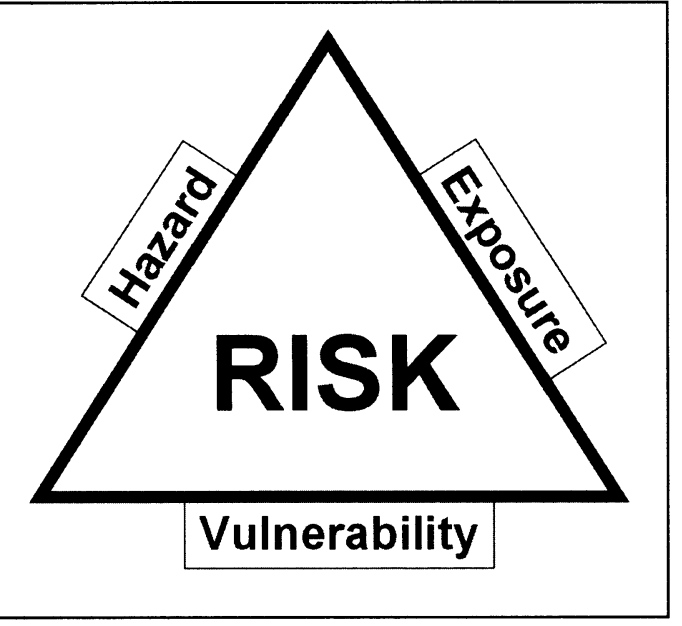

Fig. 1 - Main components of flood risk

be for better understanding of erosional-accumulational processes during floods flows used also when studying geomorphological manifestations of floods (flood geomorphology). The part of anthropogenous factors in emergence and course of floods can be consequently determined.

Individual manifestations of human activities in landscape changes in land-use, deforestation, large-scale drainage, stream straightening and regulation, modifications in floodplain, etc., as factors of vulnerability - influence both the predisposition of the system to damages as well as the character and course of the natural hazard process itself. The impact of these changes is nevertheless bound to the other components of the risk process, i.e. exposure, hazard and other factors of vulnerability.

Vulnerability of the environment in relation to values exposed to the hazard is represented by their sensibility to damage occurrence and is decisive for the extent of damage. While the total damage potential representing the maximal possible damage due to the causal process is given by the structure, value and location of property in flood area, the resulting extent of damage differs in relation to the vulnerability of the system exposed to the hazard. In case of floods the vulnerability of socio-economic structures is reflected to the factor of exposure, for instance in the following aspects:

- Increasing dependence of the society on sophisticated technologies and communication systems. Dependence of all control systems on electric power supplies for computer, information and communication systems, on telecommunication networks and transport connections causes, in case of their collapse, chaos and greater damages than in less developed systems.

- Insufficient communication and coordination. In crisis situation, vital for rescue system is the ability to deliver the right information to the right place at the right time and in the right form. During floods in August 2002 in Czechia for instance, shortcomings in communication between providers of data on hydrological situation and the central crisis headquarters in Prague led to a false interpretation of the information about the extreme character of the flood and consequently to unnecessarily high damages caused by the ill state of preparation.

- Insufficient preparedness and incapacity to respond in time and in the right way. Due to little experience with floods, many inhabitants do not know in case of flood events what to do before the flood comes, how to respond in the right way and some of them even refuse to cooperate with the rescue system. Underestimating of the risk causes unnecessary damages and secondary costs, for instance during evacuation operations.

Vulnerability of the natural environment influences the character and intensity of processes representing the proper source of hazard. Therefore 


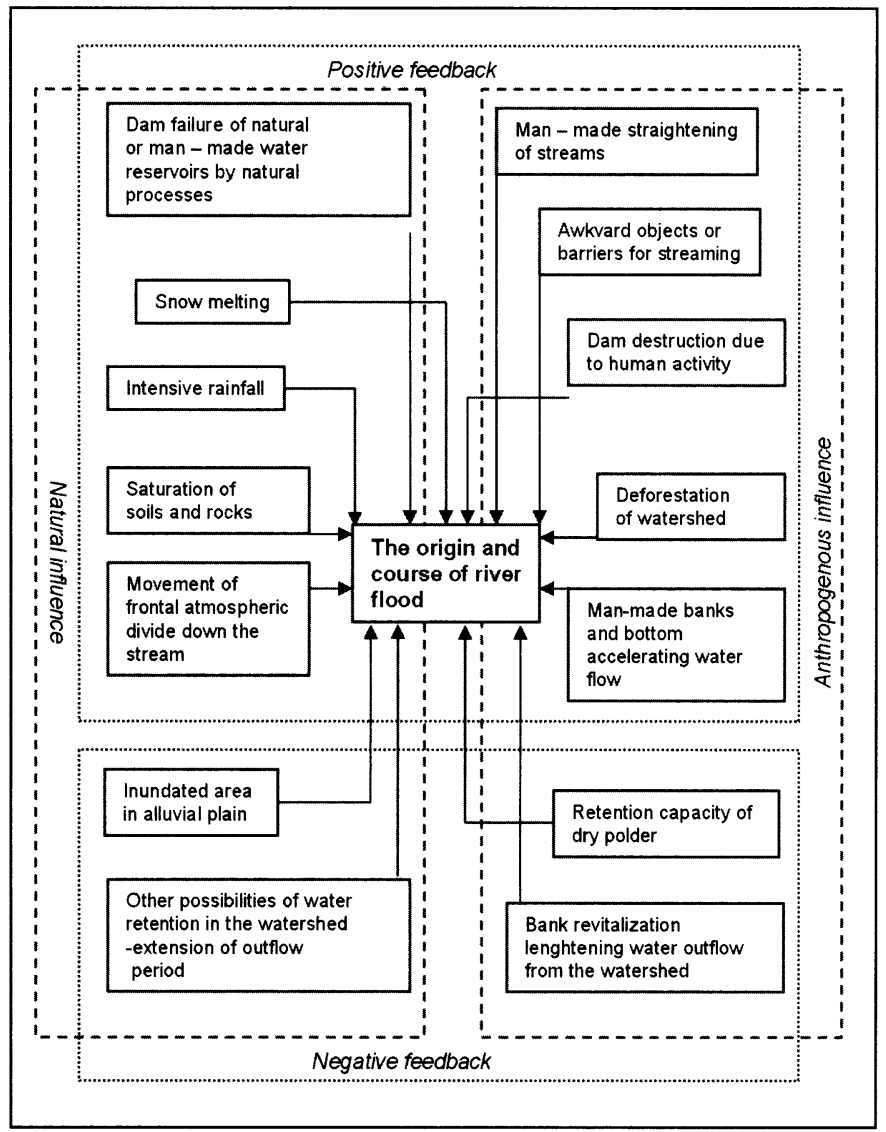

Fig. 2 - Scheme of interactions of natural and anthropogenous processes in emergence and development of river floods v u l n e r a bili t y influences the hazard component and may change the course and extreme character of a catastrophic process. As to flood risk, vulnerability factors are for instance the following:

- climatic changes causing an increase of the extreme character of atmospheric processes and of changes in their time and space distribution

- changes in landscape influencing the energetic balance of the landscape, its water-bearing capacity and runoff character

- modifications of streams and floodplains causing a lower water-bearing capacity of the floodplain and changes in streaming in riverbed.

\section{Geographical methods of assessment of anthropogenous changes in landscape}

Anthropogenous changes in landscape represent an important factor influencing the flood risk. Large changes in land-use intensity, character and structure occurring during the last centuries in cultural landscape have caused changes in runoff conditions of river basins and can thus influence also the course of floods. Among the main factors causing changes in rainfallrunoff process, mainly during extreme events, are the following:

- changes in land-use, structure and quality of landscape cover

- large-scale drainage of the landscape

- shortening of river network

- modifications of stream beds

- floodplain use structure

- presence of obstacles to water circulation in floodplain.

These manifestations of anthropogenous impacts in landscape have, during flood situations, different impact on individual runoff process components and they influence differently the development of the flood, its progression, 
transformation of flood wave or consequences of flood in the landscape. Influencing of runoff process differs in individual types of landscape modifications for different reached levels of flood extremity, in dependence on the size of the affected territory as well as according to the location in principal function areas of flood development in the area of flood wave formation, flood routing and flood spilling.

\subsection{Changes in land-use and land cover structur}

Changes in functional land-use are connected mainly with assessment of the level of natural character of individual landscape cover types. The influence of functional land-use on the runoff process is crucial and sudden and large land-use changes may have a crucial impact during extreme events.

When evaluating the impact of the present land-use and of its changes on the runoff process, important, besides the proper functional land-use, is also the space structure of the landscape and the quality of its vegetation cover.

Among land-use changes occurring simultaneously with the development of civilization, the most important for the runoff process are the following:

- deforestation of the landscape

- intensive farming

- landscape urbanization

- industrialization.

\subsubsection{Deforestation of the landscape}

Physical presence of natural landscape elements - forests and meadows in a basin is considered as a key element influencing the character of the rainfall-runoff process. Forests positively influence retention of water in the basin, transformation of flood wave or its spreading into a longer time period and the related lowering of culmination flow and timing of concurrence of runoff waves from partial catchments (see Maidment 1993). Transformation function of forests differs according to the species composition of the forest, its age, growth and health state and the character of forestry; an important part is played also by geographical characteristics - character of relief, hydrographic network, total forest coverage and spatial distribution of causal rainfall. The greatest influence on the flood course has deforestation of the landscape in the area of flood wave development, i.e. mostly in mountain areas and generally in headwater areas where vegetation interception plays a major part in the rainfall-runoff process.

The runoff process is negatively influenced mostly by deforestation and forest dieback as they weaken the retention capacity and at the same time contribute to degradation and removal of the upper soil layer. Anthropogenous interventions into agricultural landscape, as consolidation of land, unsuitable cultivation methods and soil compression by heavy vehicles, contribute to an accelerated runoff from the basin (Munich Re 1997).

A very important factor of runoff formation during floods is also the forestry character. Building of hard forest communications used by heavy vehicles contributes, mainly in slopy terrains, to an intensive concentration of surface runoff; during heavy rainfall a secondary hydric network is thus formed and water is carried away from the forested area much quicklier than in less intensively used areas. 
Intensive agricultural production as a result of growing total consumption of our society is connected mainly with the second half of the 20th century, nevertheless deep interventions into landscape connected with farming have been accompanying human society for long years.

The impact of transformation of original natural landscape elements meadows, pastures and forests into intensively farmed areas - on the runoff process is well described in literature. From the viewpoint of extreme rainfallrunoff events, it manifests mainly by a loss of retention capacity of soil and of agricultural territory as a whole. Differences in retention capacity of agricultural land, forests or natural meadows are in orders and during floods they influence the changed capacity of the landscape to transform the runoff wave.

In addition, intensive farming is often accompanied by a large-scale drainage of the territory which, mainly under the form of open drainage systems, influence the acceleration of runoff from the landscape, insufficient usage of soil retention capacity and changes in timing of runoff waves.

\subsection{Large-scale drainage of the landscape}

Systematic drainage of landscape affects mainly areas with intensive agricultural production where drainage systems are built in view to use the maximum of the territory for crop growing and to maximize the profits from farming.

As far as runoff process is concerned, we differentiate two main forms of drainage, both having a different effect.

The open drainage systems (open drains) have a clearly negative impact on the landscape, as they concentrate the surface runoff and accelerate water runoff from the landscape without using its retention potential. This causes a very steep gradient of the runoff wave, increase of culmination flows on lower reaches, changes in runoff wave timing and a lower transformational effect of the landscape on flood runoff.

On the contrary the closed drainage systems (closed drains) have a positive impact on the runoff as they increase water infiltration into soil, thus reduce surface runoff and at the same time form above drains a greater retention space than undrained soil could have formed. It results into a more effective transformation of flood wave, reduction of culmination flow and spacing of flood wave in time. Culmination of runoff from drainage systems occur as a rule later than culmination in recipient, but at the same time it precedes culmination from surface and subsurface runoff from not drained areas. Their mechanism is limited by infiltration capacity of soil and when exceeded, the drainage ceases to have any impact on the runoff.

The positive effect of closed drains is logically the highest during small floods and in initial stages of large floods when a more effective transformation of surface runoff reduces at least partly the culmination flow. During extreme floods when the project capacity of the drainage system is exceeded, the system is menaced by flooding and destruction accompanied by a significant erosion and material damages. The overall impact of drains on runoff during floods is, according to recent findings, sensibly lower than generally expected. Hladný et al.. (1998) indicate than during floods in Moravia in 1997 drainage runoff influenced, according to analysis, culmination only by $2-5 \%$. 


\subsubsection{Urbanization and industrialization}

Urbanization and industrialization of landscape represent the most intensive form of transformation of original natural structures accompanied by the most radical influencing of the surface runoff process. Urbanized areas have, due to hard surfaces, a practically null retention capacity and, in addition, because of stream and waste systems canalization, they maximally accelerate surface water runoff.

Industrialized areas and mainly areas of surface mining of minerals, bring radical interventions into the hydrographic network. In industrial landscape stream beds are relocated, canalized or even piped, water is transferred from one catchment to another, water resources are intensively drawn and accumulated to different purposes. Denuded areas, where vegetation and original hydrographic network do not exist anymore, entirely lack the capacity to retain water in landscape and, consequently, the flood control is limited to technical protection only. During extreme events, when limits of protection elements are exceeded, there occur enormous damages on property and infrastructure.

\subsubsection{Changes in landscape structure}

Very important for surface runoff is also the space structure of landscape cover. During the 20th century, large-scale consolidation of agricultural land was going on in the majority of industrialized countries wishing to reach a higher economic efficiency, higher yields and profits.

This process caused disintegration of the mosaic structure of landscape and its transformation into large complexes of fields with crop monocultures. As to the surface runoff, this change has brought a general acceleration of runoff from the landscape because of removal of obstacles and natural retardation belts, initially separating individual plots. At the same time, more room has been given to water erosion and changes in flood waves timing.

\subsubsection{Changes in quality of vegetation cover}

When considering changes in landscape we must take into consideration also changes in qualitative characteristics of vegetation, mainly of forests. Because of weakening of forests by industrial emission, forests in many places are susceptible to pest attacks and to calamities when forests in large areas are dying out. Although this does not bring changes in functional usage or space structure of landscape cover, the change in vegetation quality affects in a long-time perspective parameters of the basic hydrologic balance of the affected territory.

The impact of changes in functional usage of the territory, in landscape cover structure and in vegetation quality on the runoff process is limited by the overall retention capacity of the landscape. After exceeding the soil infiltration capacity and retention capacities of the territory, the land-use element ceases to play a more important part in the runoff process. The limit, above which this change occurs, depends on physical-geographical conditions of the territory and on the character and intensity of its use, but as a rule it does not exceed the recurrence period of 5 to 10 year rainfall (fig. 3). 


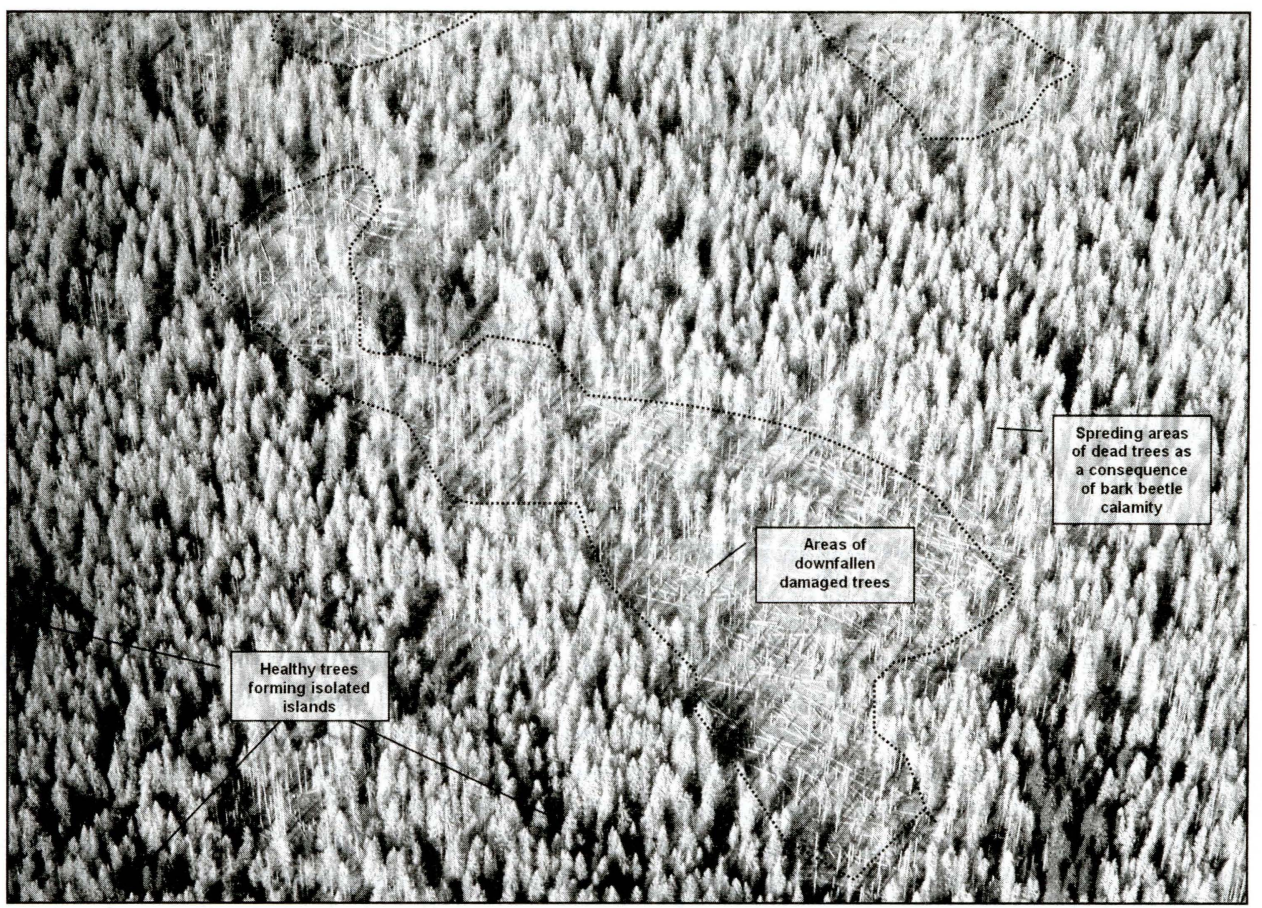

Fig. 3 - Dead forest in the Vydra River headwater area. Loss of natural hydrological function of forest in headwater area may significantly influence the runoff formation process. Photo J. Langhammer (2002).

\subsection{River network shortening}

Due to intensive land-use during the last 300 years, we assist in cultural landscape to a different intensity of river network shortening. Water streams have been straightened mainly to be used for transport of materials, to drain agricultural areas, to protect town and villages against floods or due to general urbanization and industrialization of the landscape.

Shortening of river network significantly influences water runoff from the landscape, especially during flood events. A shortening of stream length reduces the volume of river network and thus increases the part of the runoff wave volume that has to be deposited without the proper riverbed. A shortening of the stream further leads to an accelerated progression of the flood wave along the flood plain which reduces the possibilities to use its retention potential for transformation of the flood. An increased velocity of flood wave is accompanied by its increased steepness and higher water levels during culmination. At the same time, an accelerated progression of flood wave across the landscape also sensibly shortens the time necessary for preparation of flood control measures, evacuation of population and securing of property against damage.

\section{$4.4 \mathrm{Stream} \mathrm{bed} \mathrm{regulation}$}

Besides shortening of the total length of a water stream also the level of regulation of the riverbed is important for the character of the flood. 
Anthropogenous impacts can be differentiated on the level of changes in the riverbed and in changes in the longitudinal profile.

Due to intensive anthropogenous activities, the major part of water stream beds in cultural landscape are nowadays modified to a different degree, the most frequently by deepening of the bed in view to increase its capacity and to safely transport a higher flow through the given territory. Banks and bottom are usually solidified by different building processes going from stone pavements to prefabricated concrete profiles. The extreme form is stream piping, i.e. transfer of a free bed to closed pipes through which water is led generally through industrial zones, town centres and under communications.

Consolidation of banks and bottom by artificial materials leads to a reduction of hydraulic roughness of the bed in its lengthwise profile and thus to a higher velocity of water circulation in the course. During floods it results into a much steeper flood wave, higher water levels during culmination and an increase of its destructive power connected with higher erosional activities.

Especially critical for the character and level of damages caused by a flood is mainly an alteration of natural and regulated reaches. Straightened and regulated reaches increase the velocity of the flood wave and bring the water through the landscape more quickly. If a regulated reach is followed by a natural one where the roughness of the bed is naturally higher and the course is not straightened, the flood wave causes higher damages both in river bed and in regulation structures and in property in the flood plain.

An extreme increase of the risk represents during flood the piped reaches of streams. Because of a quantity of material transported by the flood, the upper sluice of pipes is quickly flooded, an artificial dam is formed which results to increased erosional and accumulational activities and as a rule also in destruction of the whole structure.

Regulation of streams in the longitudinal profile means presence of riverbed drops, weirs or dams in the riverbed. These structures modify conditions of water circulation in the stream, mainly its velocity, and significantly influence erosional and accumulational activities of the stream. Under normal hydrological conditions, weirs and drops in the bed are important for diversification of circulation in the stream, for slowing down of the runoff from regulated or straightened streams and for amelioration of oxygen conditions in streams as well as for water fauna and flora. During floods however, weirs are an obstacle to streaming and consequently localities of concentrated occurrence of erosional and accumulational manifestations of the flood. Consequences of a flood are multiplied by unsuitably located weir, as in a river bend or at the end of long intensively regulated reaches; on the contrary, near well-sized weirs and especially near the so-called movable weirs, damages are not so extensive.

\subsection{Regulation and the character of use of a floodplain}

Decisive for the capacity of a landscape to transform the flood wave is the state and character of the flood plain. The flood plain is the lowest situated part of the valley bottom in which water leaves the bed during floods. In this areas natural landscape elements should prevail, especially meadows, pastures and to a lesser degree also forests. These types of landscape cover stand also several day lasting inundation and above all they are able to retain water spilled over in the floodplain and transform the flood wave, i.e. to distribute its course over 


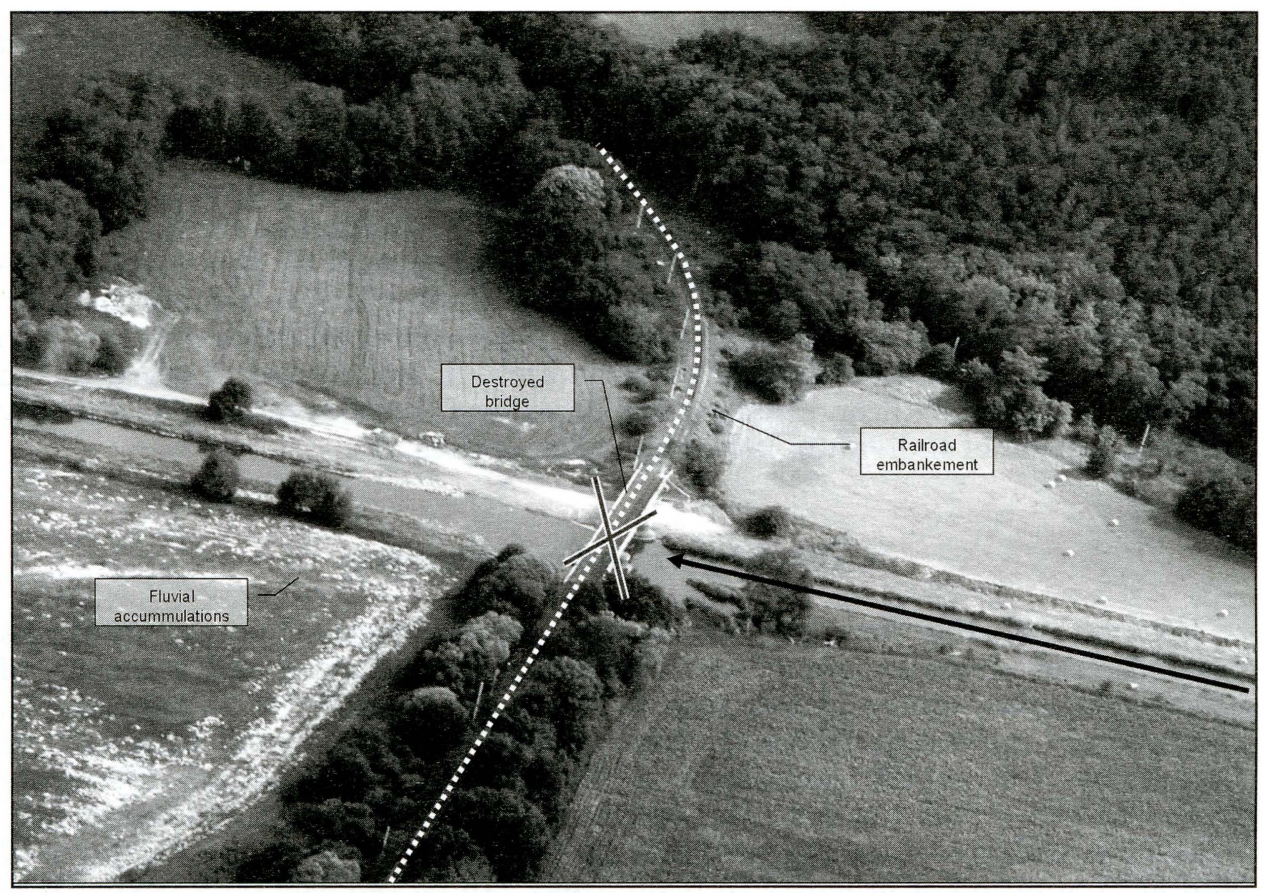

Fig. 4 - Railway bridge and embanment crossing the floodoplain of Blanice river presenting obstacle to the flood course during the flood in August 2002. Photo J. Langhammer (2002).

a longer time period and to reduce thus the culmination water level and flow. In case of its unappropriate use, transformation and retention capacities of a floodplain quickly decrease. This is mainly caused by agricultural areas, when especially arable land does not enable effective water retention in the floodplain and, in addition, it supplies material which is consequently deposited in lower reaches of the course (see Konvička 2002). Presence of agricultural areas and mainly settlements and industrial structures in floodplain causes in addition, because of possible high economic losses, demand for a more intensive modification of stream bed, mainly for an increase of its capacity, consolidation of banks or building of dams, which reduces again transformation and retention capacities of the floodplain and thus also the possibility to really and cheaply lower the flood culmination.

Obstacles to streaming are decisive for the extent of damage during floods, especially during extreme flood events when the whole floodplain is filled by water. They are unsuitably located and sized structures in floodplain as bridges, communication bodies, regulation structures on the stream or ill located buildings. Under normal hydrological conditions and during minor floods, these objects do not cause problems. During extreme events however, as sudden floods and regional floods, the impounded levels are exceeded and these objects constitute obstacles for streaming. The material transported by the flood for instance blocks up arches of bridge structures or culverts under communications; a temporary dam gets formed and then bursts. Thus not only the object itself is destroyed, but it generates a sudden flood wave which in lower reaches of the stream causes much higher damage that it would correspond to the character of the flood (fig. 4). 
Theoretical knowledge from literature and practical findings obtained when analysing the extreme flood event in August 2002 in the Otava and Blanice River catchment confirmed that historical changes in landscape use structure, shortening of water streams or the level of current modification of their beds have a crucial impact on the runoff process during flood events. The significance of anthropogenous modifications of the landscape consists mainly in their impact on the water runoff from the landscape, on the shape of the discharge wave and in a reduced possibility of its effective transformation. Possibilities of positive influencing of the flood course by interventions into the landscape structure are nevertheless limited, mainly with regard to the physical geographical conditions of the basin and the character and intensity of modification of individual landscape components.

\section{Discussion and conclusions}

Because of the rapidity of society development, mainly intensive urbanization, development of technologies, social changes and intensity of anthropogenous interventions into landscape, vulnerability represents an increasingly important factor in assessment of risks connected with natural processes. Vulnerability represents a risk element which can be, differently from the other risk components, at least partly influenced and controlled. While natural processes representing an hazard factor cannot be influenced and accumulation of property in flood areas can be reduced only partly, it is possible to target efforts to reduce vulnerability both of natural environment and social links in a way to minimize consequences of natural elements activities, to increase effectiveness of flood control measures and to reduce damages to the lowest possible level corresponding to the extent of the phenomenon.

When compared to the components of hazard and exposure, the degree of vulnerability of environment cannot be quantified so easily, as it consists from a series of indicators for which standard data, assessment indicators and standards are not available. Shortage of precise information on vulnerability concerns both social systems and natural sphere, more precisely its anthropogenous impacts. To analyse anthropogenous changes in landscape as an indicator of vulnerability within flood risk, it is possible to use methods based on geographical analysis of environment and of its elements, on analysis of historical data, including information technologies (Langhammer 2003; Langhammer, Vajskebr 2003).

The results of research into the impact of natural environment changes on flood risk carried on in the context of assessment of extreme flood events in 1997 and 2002 show clear links between physical-geographical characteristics of the basin and river network, the level of their anthropogenous transformation and their behaviour during extreme runoff events. However, they have not confirmed the hypothesis that the current level of modification of water streambeds, floodplain and landscape is the main cause of the extreme character of large floods registered in Bohemia in 2002 or in Moravia in 1997.

As main causes of anthropogenous changes in the landscape acting as a negative factor during floods, we can give changes in land-use, structure and quality of landscape cover, large-scale drainage of the landscape, shortening of river network, modification of river beds and changes in the character of the floodplain use. 
These factors have a different impact on individual components of runoff process during floods and they influence negatively the general course and consequences of floods. Intensive changes in landscape, floodplain and in river bed modification result in an accelerated runoff from the landscape, in an accelerated flow in the stream bed, in a much steeper flood wave, in changes in timing of flood waves from individual parts of the catchment, in a decrease of transformation and retention capacity of the landscape and floodplain and in resulting increase of culminations water levels and flows.

The above manifestations of changes in landscape differ by their effect at different levels of extreme floods, in addition, the individual factors acts differently at different space level of assessment.

\section{References:}

ALEXANDER, D. (1993): Natural Disasters. Routledge, London, New York, 632 p.

BARREDO, J. L., LAVALLE, C., de ROO, A. (2005): European flood risk mapping, EC DG JRC - Weather driven natural hazards, IES, Ispra, Italy, 6 p.

BOLT, B. A. et al. (1975): Geological Hazards. Springer Verlag, Berlin, Heidelberg, 328 p.

CRICHTON, D. (1999): The Risk Triangle, in Natural Disaster Management. In: Ingleton, J. (ed.): Tudor Rose, London.

HLADNY, J. et al. (1998): Vyhodnocení povodňové situace v červenci 1997. (Assessment of flood situation in July 1997.) Final report. ČHMÚ Praha, 70 p.

HZS (2006): Krizové a havarijní plánování (Crisis and breakdown planning). Hasičský záchranný sbor, Praha, http://www.hzspraha.cz.

KRON, W. (2003): Flood Disasters: causes - losses - prevention from an international reinsure`s viewpoint, in Precautionary Flood Protection in Europe, pp 1-16.

KUKAL, Z. (1982): Pŕírodní katastrofy (Natural catastrophes). Horizont, Praha, 252 p.

LANGHAMMER, J. (2003): Anthropogenic Transformation of River Network in the Otava River Basin. Acta Universitatis Carolinae-Geographica, XXXVIII, No. 2, pp. 139-156.

LANGHAMMER, J., VAJSKEBR, V. (2003): Historical Shortening of River Network in the Otava River Basin. Acta Universitatis Carolinae-Geographica, XXXVIII, No. 2, pp. 109-124.

MAIDMENT, D. R. ed. (1993): Handbook of Hydrology. Mc-Graw-Hill, New York.

TRIZNA, M. (1998): Identifikácie a hodnotenie povodňovej hrozby a povodňového rizika (Identification and assessment of flood hazard and risk). PrF UK, Bratislava.

VILES, H. A. (2005): Can stone decay be chaotic? Geological Society of America, Special Paper 390, pp. 11-16.

VILÍMEK, V. (2003): Floods in the context of natural hazards and risks. Acta Universitatis Carolinae-Geographica, XXXVIII, No. 2, pp. 5-18.

Shrnutí

\section{SOUČASNÉ PŘÍSTUPY K HODNOCENÍ ANTROPOGENNÍCH ZMĚN V KRAJINĚ JAKO FAKTORU POVODŇOVÉHO RIZIKA}

Článek se metodicky zabývá systémovým pohledem na hodnocení rizika ve vztahu k antropogenním změnám v krajině. Analyzovány jsou hlavní př́istupy k hodnocení rizika - ekonomický přístup, hodnotící riziko jako funkci pravděpodobnosti výskytu a potenciální ztráty a procesní přístup, hodnotící rizko jako funkci tří složek - ohrožení, expozice a zranitelnosti.

Komplexní efekt antropogenních změn v krajině je hodnocen v kontextu procesního modelu povodňového rizika. Jednotlivé typy antropgenních zásahů do krajiny zde představují faktor zranitelnosti, která zpětně ovlivňuje obě základní složky rizika - ohrožení a expozici. Jednotlivé typy antropogenních zásahů do krajiny, které jsou klíčové $\mathrm{z}$ hlediska ovlivnění odtokového procesu jsou analyzovány s ohledem na možné ovlivnění průběhu a následků povodní. 
Pro možnost praktické aplikace uvedených principů jsou prezentovány geografické metody, umožňující vyhodnocení aktuálního stavu antropogenních zásahů do krajiny a říční sítě, jejich časoprostorvé dynamiky a možností jejich kvantifikace pro účely vyhodnocení vlivu na průběh a následků povodně. Hlavní metody kvanitifikace a modelování povodňového rizika a jejich limity jsou hodnoceny s ohledem na prostorové měřítko hodnocení.

Antropogenní změny $\mathrm{v}$ krajině představují podle procesního přístupu faktor zranitelnosti, který se v souvislosti se socioekonomickým rozvojem společnosti velice dynamicky mění. Zranitelnost prostředí ve vztahu $\mathrm{k}$ hodnotám, vystaveným ohrožení, představuje jejich náchylnost ke vzniku škody a rozhoduje o rozsahu škod. Rozsáhlé změny v intenzitě, charakteru a struktuře využití území, ke kterým v kulturní krajině v posledních staletích dochází, působí na změny odtokových poměrů povodí a mohou tak ovlivňovat průběh povodní.

Význam zranitelnosti $\mathrm{v}$ kontextu povodňového rizika je proměnlivý $\mathrm{v}$ důsledku působení řady činitelů. Mezi klíčové patří extremita jevu, prostorové měřítko hodnoceného území, geografické charakteristiky území a v neposlední řadě celková intenzita a prostorová struktura antropogenních zásahů do povodí a toků.

Vliv antropogenních zásahů do toků, údolní nivy a povodí na průběh a následky povodní je často předmětem diskusí, kdy na jedné straně dochází $\mathrm{k}$ jeho bagatelizaci, na straně druhé $\mathrm{k}$ nadhodnocování. Je nesporné, že antropogenní zásahy do prostředí povodí vyvolávají odezvu v podobě ovlivnění srážkoodtokového procesu, ovlivnění průběhu povodňové vlny, jejích charakteristik, ovlivnění rozsahu a doby trvání rozlivu. Tato odezva je však odlišná v závislosti na výše uvedených činitelích, zejména na extremitě povodně. Vliv určitých typů modifikací krajiny a údolní nivy jako je např. napřímení a úpravy koryt toků, odvodnění zemědělskýc ploch a změny landuse, je nejvyšší u povodní s nízkou extremitou. Naproti tomu účinek jiných úprav toků a nivy, zejména výskytu překážek proudění, je naopak nejvyšší u extrémních událostí, kdy je do odtoku zapojen celý prostor údolní nivy. Tato zjištění korespondují s výsledky terénního mapování následkủ povodní, prováděných na územích, zasažených extrémními povodněmi v letech 1997 a 2002.

Zranitelnost v rámci systému přírodních rizik zároveň představuje prvek, který je možné na rozdíl od ostatních komponent rizika cíleně ovlivňovat a řídit. Zatímco přírodní procesy, které představují zdroj ohrožení nelze ovlivnit a akumulaci majetku v záplavových zónách lze snižovat jen obtížně, na snížení zranitelnosti je možné aktivně působit. Zranitelnost je možné ovlivňovat formou konkrétních úprav a zásahů, na úrovni legislativy, formou ekonomických nástrojů či nástrojů územního plánování tak, aby docházelo $\mathrm{k}$ minimalizaci následků působení přírodních živlů a omezení rozsahu škod pouze na nezbytnou úroveň, odpovídající extremitě jevu.

Obr. 1 - Hlavní komponenty povodňového rizika. Zleva: ohrožení, riziko, expozice, zranitelnost.

Obr. 2 - Schéma interakcí mezi přírodními a antropogenními procesy v rámci povodňového rizika

Obr. 3 - Mrtvý les v pramenné oblasti povodí Vydry. Ztráta hydrologické funkce lesa může významně ovlivnit odtokový proces. Zleva: zbývající zdravé stromy představující izolované ostrovy, padlé odumřelé stromy, rozšiřující se oblast odumírajících stromů jako důsledek kůrovcové kalamity.

Obr. 4 - Železniční most a násep trati protínající údolní nivu Blanice představující překážku proudění při povodni v srpnu 2002. Zleva: fluviální akumulace, stržený most, násep trati.

(Authors are with Charles University in Prague, Faculty of Science, Department of

Physical Geography and Geoecology, Albertov 6, 12843 Praha 2, Czechia;

e-mail: langhamr@natur.cuni.cz, vilimek@natur.cuni.cz.)

Arrived to the editorial board on August 28, 2006 